\title{
Brain-derived neurotrophic factor/ tropomyosin-related kinase B pathway in gastric cancer
}

\author{
Y Okugawa ${ }^{1}$, K Tanaka $^{1}$, Y Inoue ${ }^{1}$, M Kawamura ${ }^{1}$, A Kawamoto $^{1}$, J Hiro ${ }^{1}$, S Saigusa ${ }^{1}$, Y Toiyama ${ }^{1}$, M Ohi $^{1}$, \\ K Uchida ${ }^{1}, Y$ Mohri $^{1}$ and M Kusunoki ${ }^{\star, 1}$ \\ ${ }^{1}$ Department of Gastrointestinal and Pediatric Surgery, Division of Reparative Medicine, Institute of Life Sciences, Mie University \\ Graduate School of Medicine, Tsu 514-8507, Japan
}

Background: Brain-derived neutrophic factor (BDNF) is a member of the neutrophin family that is known to activate the highaffinity tropomyosin-related receptor kinase B (TrkB). This study aimed to clarify the clinical and biological significance of the BDNF/TrkB pathway in gastric cancer.

Methods: We analysed BDNF and TrkB expression in gastric cancer samples by real-time reverse transcription PCR and immunohistochemistry. To investigate the biological role of BDNF/TrkB axis, recombinant human BDNF (rhBDNF) and the Trk antagonist K252a were used for in vitro and in vivo analysis.

\begin{abstract}
Results: The BDNF expression at the invasive front of primary tumours was significantly elevated compared with that in the tumour core and adjacent normal mucosa. Increased BDNF expression at the invasive front was significantly correlated with factors reflecting disease progression, and poor prognosis. Increased co-expression of the BDNF/TrkB axis was significantly correlated with poor prognosis. Gastric cancer cells expressed BDNF, and administration of rhBDNF promoted proliferation, migration, invasion, and inhibition of anoikis. These effects were generally inhibited by K252a. In an in vivo assay, BDNF(+)/TrkB $(+)$ gastric cancer cells injected into nude mice established peritoneal dissemination, whereas K252a inhibited tumour growth.
\end{abstract}

Conclusion: The BDNF/TrkB pathway might be deeply involved in gastric cancer disease progression.

Despite a decline in its incidence, gastric cancer remains the second leading cause of cancer death worldwide (Ferlay et al, 2010). At the time of initial diagnosis, many cases have already reached an advanced stage where tumour cell spreading has occurred. For better diagnosis and treatment of gastric cancer, identification of the pathways responsible for disease development and progression is critical.

Brain-derived neurotrophic factor (BDNF) belongs to the neurotrophin family and is known to activate the high-affinity tropomyosin-related receptor kinase $\mathrm{B}(\operatorname{TrkB})$ receptor. The $\mathrm{BDNF} / \mathrm{TrkB}$ pathway has a key role in the development of the nervous system and participates in regulating neuronal survival, differentiation, and activity through synaptic modulation (Lewin and Barde, 1996; Segal and Greenberg, 1996). Douma et al (2004) demonstrated that TrkB generates a specific and potent prosurvival signal that renders epithelial cells resistant to anoikis, whereupon they acquire potent tumorigenic, invasive, and metastatic capacities. Several studies indicated that BDNF and/or its receptor, TrkB, might be involved in cancer growth and metastasis in several malignant tissues, such as neuroblastoma (Aoyama et al, 2001), pancreatic ductal carcinoma (Miknyoczki et al, 1999), prostate cancer (Montano and Djamgoz, 2004), lung cancer (Ricci et al, 2001), and hepatocellular carcinoma (Yang et al, 2005). The TrkB activation by BDNF was shown to enhance the 
proliferation and survival of transitional cell carcinoma cell lines, whereas a TrkB antagonist suppressed their migration and invasion (Huang et al, 2010a, b). Previously, we used RNA interference in colorectal cancer (CRC) cells to demonstrate that high levels of TrkB transcript expression is associated with poor prognosis in CRC patients and enhanced malignant potential in terms of proliferation, migration, invasion, and anoikis inhibition (Fujikawa et al, 2012). In addition, in gastric cancer patients, we revealed that high TrkB transcript expression is an independent prognostic marker (Tanaka et al, 2009).

Although a growing number of studies demonstrated the function of the BDNF/TrkB axis in experimental systems, to date no reports have shown a biological function of the BDNF/TrkB pathway in gastric cancer cell lines or a correlation between BDNF/ TrkB expression and clinicopathological variables, including prognosis. The aim of this study was therefore to determine the relationship between $\mathrm{BDNF} / \mathrm{TrkB}$ expression determined by immnohistochemical analysis and clinicopathological findings in gastric cancer patients and to reveal the function of the BDNF/ TrkB axis in gastric cancer in vitro and in vivo.

\section{MATERIALS AND METHODS}

Patients and sample collection. A total of 150 patients (119 men and 31 women) of our study, accompanied with the availability of cancer fresh frozen samples with complete clinical data, the quality of isolated RNA for real-time PCR, and preserved highquality paraffin block of resected primary cancer specimen, were consecutive patients who underwent surgery for gastric cancer from January 2000 to November 2009 at Mie University Hospital, Japan. Further information is provided in the Supplementary Data. The study design was approved by the Mie University institutional review board, and written informed consent was obtained from all patients.

Immunohistochemical analysis. Immunohistochemical analysis was performed as described previously (Fujikawa et al, 2012). A primary rabbit polyclonal antibody against BDNF (H-117, 1:350; Santa Cruz Biotechnology, Santa Cruz, CA, USA) and primary mouse monoclonal antibody against TrkB (1:100; R\&D Systems, Foster City, CA, USA) were used in a labelled streptavidin-biotin method (LASB2 kit/HRP; Dako Cytomation, Carpinteria, CA, USA). Negative controls were also run simultaneously.

Evaluation of the degree of antibody reactivity. The immunoreactivity of BDNF and TrkB in each primary gastric cancer was separately scored for the tumour invasion front (usually $<0.5 \mathrm{~mm}$ broad in tumour periphery) and the core of the tumour (centre of the tumour in general, excluding the invasion front and necrotic areas), as previously described (Alpizar-Alpizar et al, 2011), by scanning the whole section at medium $(\times 50)$ and high magnification $(\times 200)$ as: no staining, 0 ; weak staining, light yellow, 1 ; moderate staining, yellowish brown, 2; and strong staining, brown, 3. The slides were evaluated three times by three independent investigators (YO, KT and SS) who were blinded to the nature of the specimens and antibodies used. To compare the expression of BDNF and/or TrkB with clinical and pathological parameters, samples were grouped in high (staining intensity $>$ median immunohistochemical score $=1$ ) and low-expression groups (staining intensity $\leqslant$ median immunohistochemical score $=1$ ) as described previously (Kahlert et al, 2011). In addition, BDNF expression was further analysed by dichotomised as upregulation group (staining intensity: invasive front $>$ core site) and no change or downregulated group (staining intensity: invasive front $\leqslant$ core site).
Total RNA extraction, cDNA synthesis, and semi-quantitative RT-PCR. Tumour specimens and gastric cancer cell lines were homogenised with a Mixer Mill MM 300 homogeniser (Qiagen, Chatsworth, CA, USA). Total RNA was isolated using an RNeasy mini kit (Qiagen) according to the manufacturer's instructions. cDNA was synthesised from $5.0 \mathrm{mg}$ total RNA with a random hexamer primer and Superscript III reverse transcriptase (Invitrogen, Carlsbad, CA, USA) according to the manufacturer's instructions. Semi-quantitative PCR (qPCR) analysis was performed using the TaqMan Universal PCR Master Mix (Applied Biosystems, Foster City, CA, USA). The relative abundance of target transcripts that were measured using TaqMan probes for BDNF (Assay ID, Hs00380947_m1, TaqMan Gene Expression Assays; Applied Biosystems) and Ntrk2 (Assay ID, Hs00178811_m1; Applied Biosystems) was normalised to the expression level of $\beta$-actin (Assay ID, Hs01060665_g1; Applied Biosystems). TaqMan probes for BDNF corresponded to exon 1-2 of BDNF transcript variant 5 (NCBI reference sequence: NM_170733.3). Amplified products were separated electrophoretically, visualised, and photographed under UV light after ethidium bromide staining, and quantified by CA Analyser version 2.0 (ATTO Corporation, Tokyo, Japan). Densitometry analyses were performed using ImageJ software (National Institutes of Health, Bethesda, MD, USA).

Real-time quantitative RT-PCR and relative expression level of BDNF. Quantitative PCR analysis was performed using the TaqMan Universal PCR Master Mix (Applied Biosystems). The relative abundance of target transcripts that were measured using TaqMan probes for BDNF (Assay ID, Hs00380947_m1; Applied Biosystems) was normalised to the expression level of GAPDH (Assay ID, Hs02758991_g1; Applied Biosystems) and evaluated using Applied Biosystems StepOne Software v2.1. The relative BDNF gene-expression level was determined by the standard curve method. Further information is provided in the Supplementary Data.

Cell lines. Human gastric cancer cell lines MKN7 (intestinal type), MKN74 (intestinal type), MKN45 (diffuse type), KATO III (diffuse type) and NUGC3 (diffuse type) were obtained from the Cell Resource Center for Biomedical Research, Tohoku University. These cell lines have been tested and authenticated. These cell lines were maintained in RPMI-1640 medium supplemented with $10 \%$ fetal bovine serum, $100 \mathrm{IU} \mathrm{ml}^{-1}$ penicillin, and $100 \mathrm{~g} \mathrm{ml} \mathrm{ml}^{-1}$ streptomycin at $37^{\circ} \mathrm{C}$ and $5 \% \mathrm{CO}_{2}$.

Western blot analysis. Western blotting was performed as described previously (Toiyama et al, 2011). Immobilon membranes (Millipore, Billerica, MA, USA) were incubated with the respective anti-human primary antibody at the recommended dilution (antiBDNF, TrkB, p-AKT, p-ERK, E-cadherin, $\beta$-actin (Santa Cruz Biotechnology)).

Pharmaceutical reagents. Recombinant human BDNF (rhBDNF) was purchased from PeproTech (Rocky Hill, NJ, USA) and prepared according to the manufacturer's instructions. K252a was purchased from (Calbiochem, San Diego, CA, USA) and stored at $-20{ }^{\circ} \mathrm{C}$ before use in vitro. K252a was dissolved in PBS before animal injection.

Proliferation, cell cycle, invasion, migration, and anoikis assays. In order to assess the effect of BDNF on proliferation, invasion, and migration, $100 \mathrm{ng} \mathrm{ml}^{-1} \mathrm{rhBDNF}$ was used. To investigate the relationship of BDNF and TrkB, we used $50 \mathrm{nM}$ Trk antagonist K252a. Effects of rhBDNF on GC cell lines were compared with untreated cells, cells treated with K252a, or with cells pre-treated with K252a for $2 \mathrm{~h}$ followed by rhBDNF. Further information is provided in the Supplementary Data. 
In vivo studies. Male nude mice $(\mathrm{BALB} / \mathrm{c})$ at 8 weeks of age were obtained from Japan SLC. The treatment protocol followed the guidelines for animal experimentation adopted by Mie University, and meets the standards required by the UKCCCR guidelines (Workman et al, 2010). The experimental protocols were reviewed and approved by the Animal Care and Use Committee at the Mie University Graduate School of Medicine. NUGC cells $\left(2 \times 10^{6}\right.$ cells per $1 \mathrm{ml}$ PBS) were injected into mice intraperitoneally to generate peritoneal metastasis of gastric cancer. To examine the effect of $\mathrm{K} 252 \mathrm{a}$ on the peritoneal dissemination potential of gastric cancer cells, $1 \mathrm{ml}$ dissolved $\mathrm{K} 252 \mathrm{a}\left(500 \mu \mathrm{g} \mathrm{kg}^{-1}\right.$ ) or $1 \mathrm{ml}$ PBS (control) was injected intraperitoneally 14 days after carcinoma cell injection. Mice were killed 35 days after the injection of carcinoma cells, and intraperitoneal dissemination was evaluated $(n=5)$.

Statistical analysis. Statistical analysis was performed using StatView software (version 5; Abacus Concepts, Inc., Berkeley, CA, USA). Results are expressed as means \pm s.e. Differences between groups were estimated by the Pearson's $\chi^{2}$-test, repeated-measures analysis of variance analysis, or unpaired
A

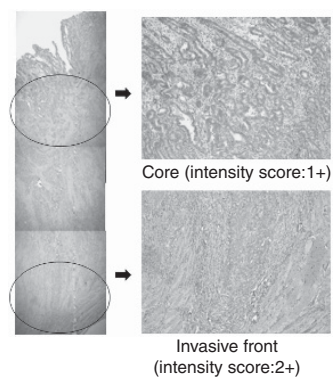

C

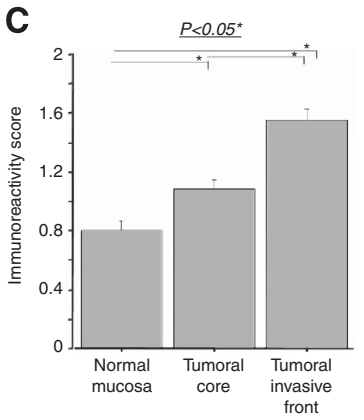

B

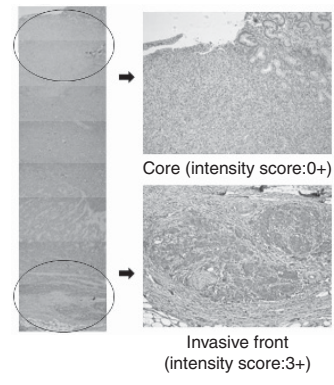

D

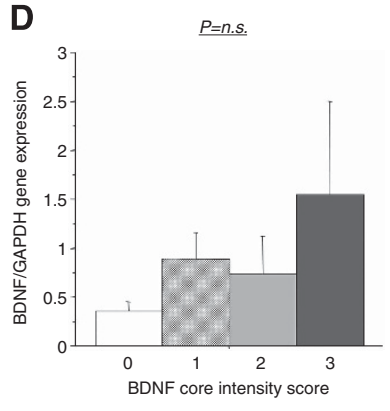

E

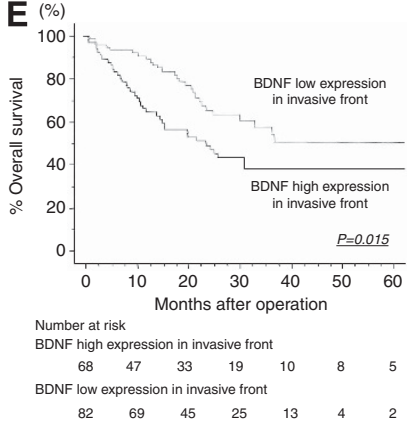

$\mathbf{G}^{(\%)}$

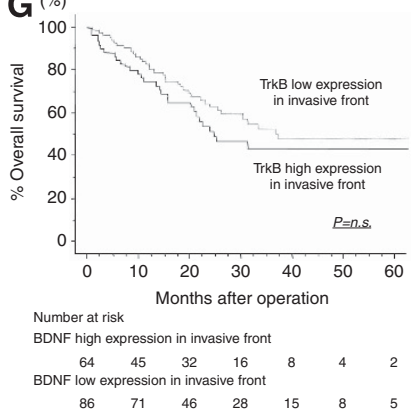

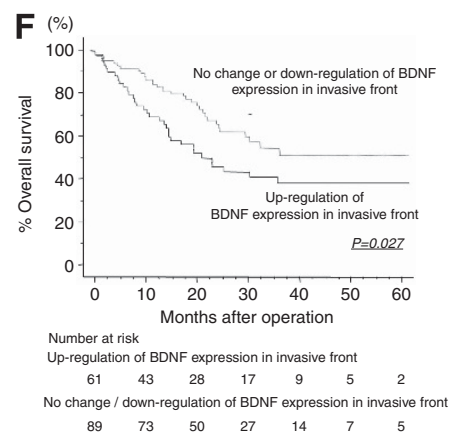

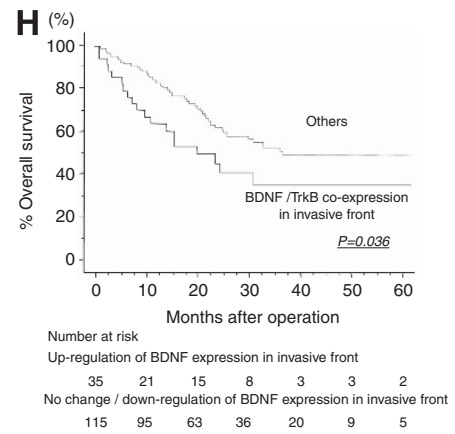

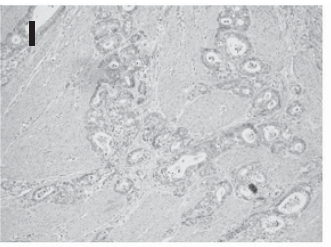
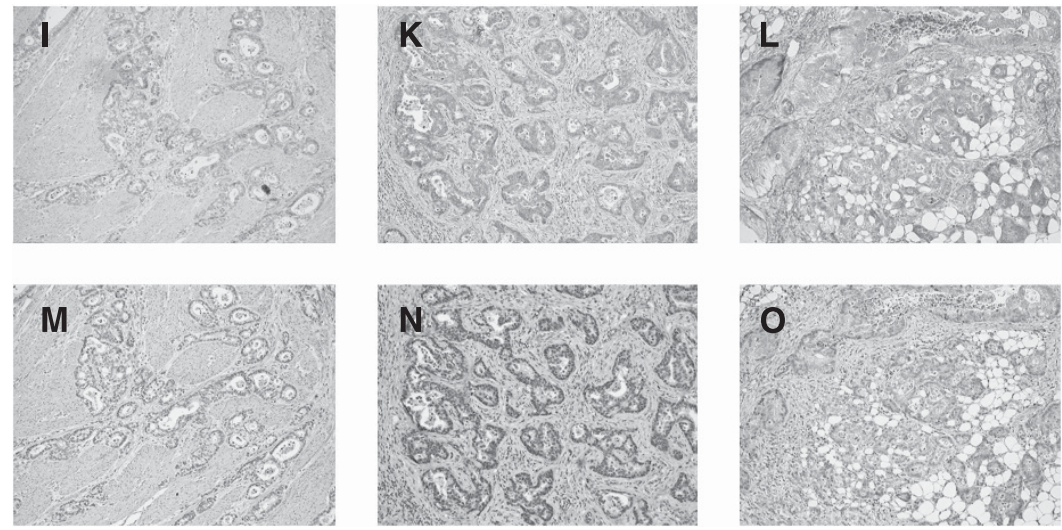

Figure 1. (A, B) Representative example of upregulated immunohistochemical BDNF staining in the tumour invasive front of primary gastric cancer compared with that in the tumour core. (A, B: original magnification: $\times 40$ and $\times 100$, respectively). In these representative images, BDNF immunoreactivity in each primary gastric cancer was scored as: no staining, 0; weak staining, 1; moderate staining, 2; and strong staining, 3 . (C) Immunohistochemical intensity scoring in primary gastric cancer and adjacent normal mucosa. BDNF expression in cancerous tissues was significantly higher than that in adjacent normal mucosa $(P<0.05)$. In addition, BDNF expression at the tumour invasive front was significantly higher than that in the tumour core $(P<0.05)$. (D) Quantitative real-time PCR analyses of BDNF gene expression relative to GADPH in tumour core tissue specimens. The BDNF gene expression had a gradient elevation pattern similar to the increased immunohistochemical intensity, although they had no significant differences. (E-H) Kaplan-Meier survival curves of gastric cancer patients according to BDNF expression at the tumour invasive front based on immunohistochemical analysis. (E) The BDNF expression change comparing tumour invasive front and core (F) The TrkB expression in the tumour invasive front (G), and BDNF/TrkB co-expression in the tumour invasive front (H). (I-N) Representative example of positive immunohistochemical staining of BDNF and TrkB in a primary (I: BDNF, L: TrkB, original magnification $\times 100)$ and disseminated lesion of the lymph node $(\mathrm{J}: \mathrm{BDNF}, \mathbf{M}$ : TrkB, original magnification $\times 100)$ and peritoneum $(\mathbf{K}: \mathrm{BDNF}, \mathbf{N}$ : TrkB, original magnification, $\times 100)$ from the same gastric cancer patient. BDNF and TrkB were also expressed in disseminated cancer cells of the lymph node and peritoneum in the same pattern as that observed in primary lesions of gastric cancer. 
Student's $t$-test. Actuarial survival curves were obtained using the Kaplan-Meier method, and comparisons were made using logrank tests. Two-sided $P$-values $<0.05$ were considered to be statistically significant.

\section{RESULTS}

Brain-derived neutrophic factor overexpression at the invasive front of gastric cancer. The BDNF immunohistochemical studies revealed that the BDNF protein was mainly expressed in the cytoplasm of gastric cancer cells. Moreover, many cases had BDNF expression that was upregulated at the invasive front of primary gastric cancer compared with the corresponding tumour core (Figure $1 \mathrm{~A}$ and $\mathrm{B}$ ).

In clinical samples obtained from patients with gastric cancer, immunohistochemical analysis revealed that BDNF expression in cancerous tissues was significantly higher than that in adjacent normal mucosa (tumour-invasive front: $1.55 \pm 0.85$; tumour core: $1.09 \pm 0.77$; adjacent normal mucosa: $0.81 \pm 0.72, P<0.05$, respectively). In addition, BDNF expression at the tumour invasive front was significantly higher than that in the tumour core (Figure 1C). However, because evaluation by immunohistochemistry alone may be insufficient to determine whether BDNF is truly expressed, we evaluated BDNF expression by real-time quantitative RT-PCR. Expression values (relative mRNA levels) of BDNF were expressed as ratios between the gene of interest (BDNF) and an internal reference gene (GAPDH), which provided a normalisation factor for the amount of RNA. Relative BDNF gene expression was correlated with the BDNF expression score of the tumour core site in gastric cancer patients (Figure 1D).

Clinical significance of BDNF overexpression at the invasive front of gastric cancer. Table 1 shows the relationship between $\mathrm{BDNF}$ expression at the tumour invasive front and clinicopathological variables in tumour specimens from gastric cancer patients. Elevated BDNF expression was significantly associated with younger age $(<69)$, vessel involvement, lymph node metastasis, and peritoneal dissemination. Patients with elevated BDNF expression at the tumour invasive front also had significantly poorer prognoses than those in the low-expression group (log-rank test, $P=0.015$ ) (Figure $1 \mathrm{E}$ ). In addition, patients with BDNF upregulation at the tumour invasive front compared with the tumour core had significantly poorer prognoses than those with equal or downregulated BDNF expression (log-rank test, $P=0.027$ ) (Figure 1F).

Brain-derived neutrophic factor/TrkB co-expression was significantly correlated with poor prognosis in gastric cancer. Immunohistochemical studies revealed that the TrkB protein was mainly expressed in the nucleus and cytoplasm of gastric cancer cells. Although TrkB expression at the tumour invasive front did not show a significant correlation with prognosis, the BDNF/TrkB co-expression group, where both BDNF and TrkB have high expression above cutoff levels, showed significantly worse prognoses than the other groups (log-rank test, $P=0.036$ ) (Figure $1 \mathrm{G}$ and $\mathrm{H}$ ). Table 2 shows the relationship between TrkB or BDNF/ TrkB expression at the tumour invasive front and clinicopathological variables in gastric cancer patients. Besides the significant correlation with histological intestinal type, elevated TrkB expression had a tendency to be correlated with lymph node metastasis. The BDNF/TrkB co-expression was significantly associated with histological intestinal type and lymph node metastasis.

Immunohistochemical staining of BDNF and TrkB in gastric cancer tissues, lymph node metastasis, and peritoneal carcinomatosis. Immunohistochemical analysis revealed that BDNF and TrkB proteins were highly expressed in primary gastric cancer cells
Table 1. Clinicopathological Variables and BDNF expression in invasive front in 150 gastric cancer patients

\begin{tabular}{|l|r|c|c|c|}
\hline \multicolumn{5}{|c|}{ BDNF expression } \\
\hline Variable & $\boldsymbol{n}$ & High $(\boldsymbol{n}=\mathbf{6 8})$ & Low $(\boldsymbol{n}=\mathbf{8 2})$ & $\boldsymbol{P}$ \\
\hline Gender & 119 & 52 & 67 & $0.431^{\mathbf{b}}$ \\
\hline Male & 31 & 16 & 15 & \\
Female & &
\end{tabular}

\begin{tabular}{|l|l|l|l|l|}
\hline \multicolumn{7}{|l|}{ Age (years) } \\
\hline$<69$ (median) & 71 & 42 & 37 & $0.042^{\mathrm{a}, \mathrm{b}}$ \\
$\geqq 69$ & 79 & 26 & 45 & \\
\hline
\end{tabular}

Tumour size

\begin{tabular}{|l|l|l|l|l|}
\hline$\geqslant 5.5 \mathrm{~cm}$ (median) & 76 & 37 & 39 & 0.404 \\
$<5.5 \mathrm{~cm}$ & 74 & 31 & 43 & \\
\hline
\end{tabular}

Histological type

\begin{tabular}{|l|l|l|l|l|}
\hline Intestinal type & 75 & 32 & 43 & $0.512^{\mathbf{b}}$ \\
Diffuse type & 75 & 36 & 39 & \\
\hline
\end{tabular}

Pathological T category

\begin{tabular}{|l|l|l|l|l|}
\hline PT1/2 & 52 & 19 & 33 & $0.115^{\mathbf{b}}$ \\
pT3/4 & 98 & 49 & 49 & \\
\hline
\end{tabular}

Vessel involvement

\begin{tabular}{|l|r|c|c|c|}
\hline+ & 119 & 61 & 58 & $0.004^{\text {a,b }}$ \\
- & 31 & 7 & 24 & \\
\hline
\end{tabular}

Lymphatic vessel involvement

\begin{tabular}{|c|c|c|c|c|}
\hline+ & 138 & 65 & 73 & $0.140^{\mathbf{b}}$ \\
\hline- & 12 & 3 & 9 & \\
\hline
\end{tabular}

Lymph node metastasis

\begin{tabular}{|l|r|l|l|l|}
\hline N0 & 45 & 13 & 32 & $0.008^{\mathbf{a}, \mathrm{b}}$ \\
N1 & 105 & 55 & 50 & \\
\hline
\end{tabular}

Liver metastasis

\begin{tabular}{|c|c|c|c|l|}
\hline $\mathrm{H} 0$ & 138 & 63 & 75 & $0.790^{\mathbf{b}}$ \\
$\mathrm{H} 1$ & 12 & 4 & 8 & \\
\hline
\end{tabular}

Peritoneal carcinomatosis

\begin{tabular}{|l|r|l|l|l|}
\hline P0 & 123 & 51 & 72 & $0.042^{\text {a,b }}$ \\
\hline P1 & 27 & 17 & 10 & \\
\hline
\end{tabular}

Stage classification

\begin{tabular}{l|r|r|l|l|}
\hline Stage I-II & 48 & 17 & 31 & $0.094^{\mathbf{b}}$ \\
Stage III-IV & 102 & 51 & 51 & \\
\hline & \\
${ }^{\mathrm{a}} P<0.05$. & \\
${ }^{\mathrm{b}}$ Pearson's $\chi^{2}$-test.
\end{tabular}

and disseminated cancer cells of the lymph node and peritoneum in the same pattern as that observed in the primary lesions (Figure 1I-N).

BDNF promotes cell proliferation in gastric cancer cells expressing TrkB in vitro. Western blotting revealed that BDNF was detected in all gastric cancer cells tested, although semiquantitative RT-PCR analysis demonstrated that BDNF transcript variant 5 was detected only in MKN7, MKN45, and NUGC3 cells (Figure 2A). Semi-quantitative RT-PCR and western blotting revealed that TrkB was expressed in all gastric cancer cells tested, 
Table 2. Clinicopathological variables and BDNF/TrkB expression in 150 gastric cancer patients

\begin{tabular}{|c|c|c|c|c|c|c|c|}
\hline \multirow[b]{2}{*}{ Variable } & \multirow[b]{2}{*}{$n$} & \multicolumn{2}{|c|}{ TrkB expression } & \multicolumn{3}{|c|}{ BDNF/TrkB axis } & \multirow[b]{2}{*}{$\boldsymbol{P}$} \\
\hline & & High $(n=64)$ & Low $(n=86)$ & $\boldsymbol{P}$ & Co-expression $(n=35)$ & Others $(n=115)$ & \\
\hline \multicolumn{8}{|l|}{ Gender } \\
\hline $\begin{array}{l}\text { Male } \\
\text { Female }\end{array}$ & $\begin{array}{c}119 \\
31\end{array}$ & $\begin{array}{l}54 \\
10\end{array}$ & $\begin{array}{l}65 \\
21\end{array}$ & $188^{b}$ & $\begin{array}{c}29 \\
6\end{array}$ & $\begin{array}{l}90 \\
25\end{array}$ & $0.557^{b}$ \\
\hline \multicolumn{8}{|l|}{ Age $(y)$} \\
\hline $\begin{array}{l}<69 \text { (median) } \\
\geqslant 69\end{array}$ & $\begin{array}{l}71 \\
79 \\
\end{array}$ & $\begin{array}{l}30 \\
34\end{array}$ & $\begin{array}{l}41 \\
45\end{array}$ & $0.923^{b}$ & $\begin{array}{l}12 \\
23\end{array}$ & $\begin{array}{l}59 \\
56\end{array}$ & $0.078^{b}$ \\
\hline \multicolumn{8}{|l|}{ Tumour size } \\
\hline $\begin{array}{l}\geqslant 5.5 \mathrm{~cm} \text { (median) } \\
<5.5 \mathrm{~cm}\end{array}$ & $\begin{array}{l}76 \\
74 \\
\end{array}$ & $\begin{array}{l}34 \\
30\end{array}$ & $\begin{array}{l}42 \\
44\end{array}$ & $0.603^{b}$ & $\begin{array}{l}20 \\
15\end{array}$ & $\begin{array}{l}56 \\
59\end{array}$ & $0.382^{b}$ \\
\hline \multicolumn{8}{|c|}{ Histological type } \\
\hline $\begin{array}{l}\text { Intestinal type } \\
\text { Diffuse type }\end{array}$ & $\begin{array}{l}75 \\
75 \\
\end{array}$ & $\begin{array}{l}39 \\
25\end{array}$ & $\begin{array}{l}36 \\
50\end{array}$ & $0.021^{a, b}$ & $\begin{array}{l}24 \\
11\end{array}$ & $\begin{array}{l}51 \\
64\end{array}$ & $0.012^{a, b}$ \\
\hline \multicolumn{8}{|c|}{ Pathological T category } \\
\hline $\begin{array}{l}\mathrm{pT} 1 / 2 \\
\mathrm{pT} 3 / 4\end{array}$ & $\begin{array}{l}52 \\
98 \\
\end{array}$ & $\begin{array}{l}18 \\
46 \\
\end{array}$ & $\begin{array}{l}34 \\
52\end{array}$ & $0.146^{b}$ & $\begin{array}{c}9 \\
26\end{array}$ & $\begin{array}{l}43 \\
72 \\
\end{array}$ & $0.204^{b}$ \\
\hline \multicolumn{8}{|l|}{ Venous invasion } \\
\hline $\begin{array}{l}+ \\
- \\
\end{array}$ & $\begin{array}{c}119 \\
31 \\
\end{array}$ & $\begin{array}{l}51 \\
13 \\
\end{array}$ & $\begin{array}{l}68 \\
18 \\
\end{array}$ & $0.926^{b}$ & $\begin{array}{c}30 \\
5\end{array}$ & $\begin{array}{l}89 \\
26 \\
\end{array}$ & $0.287^{b}$ \\
\hline \multicolumn{8}{|c|}{ Lymphatic invasion } \\
\hline $\begin{array}{l}+ \\
-\end{array}$ & $\begin{array}{c}138 \\
12 \\
\end{array}$ & $\begin{array}{c}61 \\
3 \\
\end{array}$ & $\begin{array}{c}77 \\
9 \\
\end{array}$ & $0.197^{b}$ & $\begin{array}{c}33 \\
2\end{array}$ & $\begin{array}{c}105 \\
10 \\
\end{array}$ & $0.569^{b}$ \\
\hline \multicolumn{8}{|c|}{ Lymph node metastasis } \\
\hline $\begin{array}{l}\text { N0 } \\
\text { N1 }\end{array}$ & $\begin{array}{c}45 \\
105 \\
\end{array}$ & $\begin{array}{l}14 \\
50 \\
\end{array}$ & $\begin{array}{l}31 \\
55\end{array}$ & $0.061^{b}$ & $\begin{array}{c}5 \\
30 \\
\end{array}$ & $\begin{array}{l}40 \\
75\end{array}$ & $0.021^{a, b}$ \\
\hline \multicolumn{8}{|l|}{ Liver metastasis } \\
\hline $\begin{array}{l}\mathrm{HO} \\
\mathrm{H} 1\end{array}$ & $\begin{array}{c}138 \\
12 \\
\end{array}$ & $\begin{array}{c}58 \\
6\end{array}$ & $\begin{array}{c}80 \\
6 \\
\end{array}$ & $0.592^{b}$ & $\begin{array}{c}33 \\
2 \\
\end{array}$ & $\begin{array}{c}105 \\
10 \\
\end{array}$ & $0.569^{b}$ \\
\hline \multicolumn{8}{|c|}{ Peritoneal carcinomatosis } \\
\hline $\begin{array}{l}\mathrm{P} 0 \\
\mathrm{P} 1\end{array}$ & $\begin{array}{c}123 \\
27 \\
\end{array}$ & $\begin{array}{l}50 \\
14 \\
\end{array}$ & $\begin{array}{l}73 \\
13 \\
\end{array}$ & $0.287^{b}$ & $\begin{array}{c}27 \\
8 \\
\end{array}$ & $\begin{array}{l}96 \\
19 \\
\end{array}$ & $0.393^{b}$ \\
\hline \multicolumn{8}{|c|}{ Stage classification } \\
\hline $\begin{array}{l}\text { Stage I -II } \\
\text { Stage III-IV }\end{array}$ & $\begin{array}{c}48 \\
102 \\
\end{array}$ & $\begin{array}{l}17 \\
47 \\
\end{array}$ & $\begin{array}{l}31 \\
55 \\
\end{array}$ & $0.218^{b}$ & $\begin{array}{c}8 \\
27 \\
\end{array}$ & $\begin{array}{l}40 \\
75 \\
\end{array}$ & $0.185^{b}$ \\
\hline $\begin{array}{l}{ }^{\mathrm{a}} P<0.05 . \\
\mathrm{b}_{\text {Pearson's }} \chi^{2} \text {-test. }\end{array}$ & & & & & & & \\
\hline
\end{tabular}

although MKN45 cells showed low TrkB protein expression (Figure 2B). Among these cell lines, MKN7, MKN74, and NUGC3 cells were selected for use in in vitro analysis because of their high expression levels of both BDNF and TrkB. The rhBDNF exposure upregulated the expression of p-AKT and p-ERK in these cell lines, and these expression changes could be inhibited by treating cells with the Trk inhibitor K252a for $20 \mathrm{~min}$ after rhBDNF exposure. In these gastric cancer cells, E-cadherin impairment was detectable $24 \mathrm{~h}$ after BDNF treatment, and these phenomena could also be blocked by K252a pre-treatment (Figure 2C).
In addition, we investigated the proliferative potential of the gastric cancer cell lines MKN7, MKN74, and NUGC3 treated with rhBDNF $\left(100 \mathrm{ng} \mathrm{ml}^{-1}\right), \mathrm{K} 252 \mathrm{a}(50 \mathrm{nM})$, or K252a followed by rhBDNF. At $72 \mathrm{~h}$ after treatment, there was a significant increase in proliferation of rhBDNF-treated gastric cancer cells compared with that of untreated cells, and K252a treatment followed by rhBDNF inhibited the effect of rhBDNF in these cell lines. In addition, K252a treatment of MKN7 and NUGC3 cells without rhBDNF significantly reduced cell growth compared with that of untreated cells (Figure 3A). 

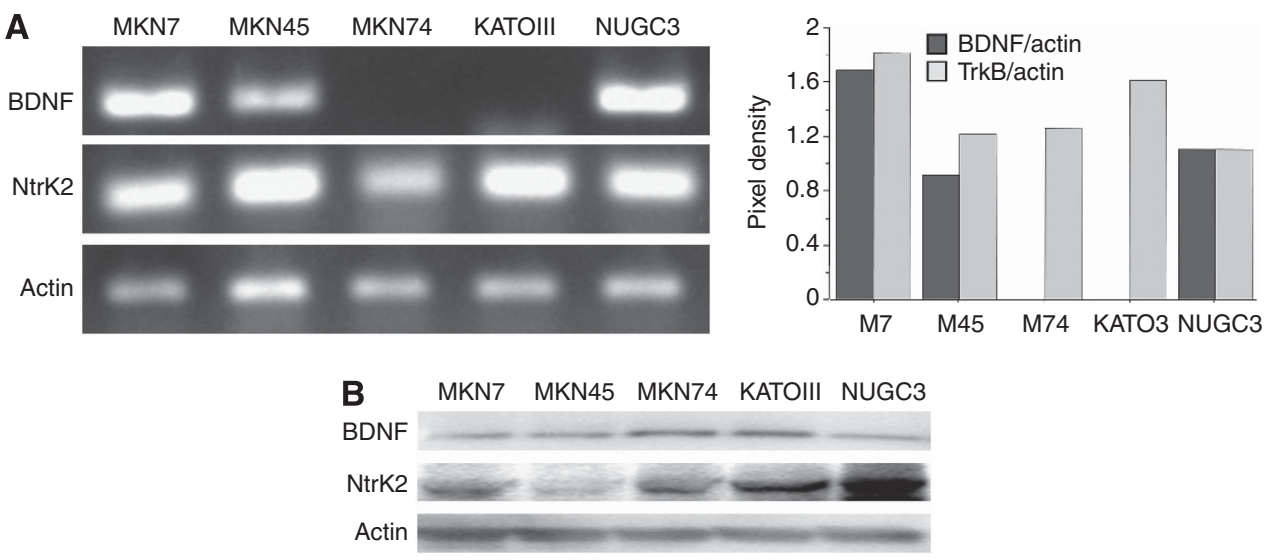

C
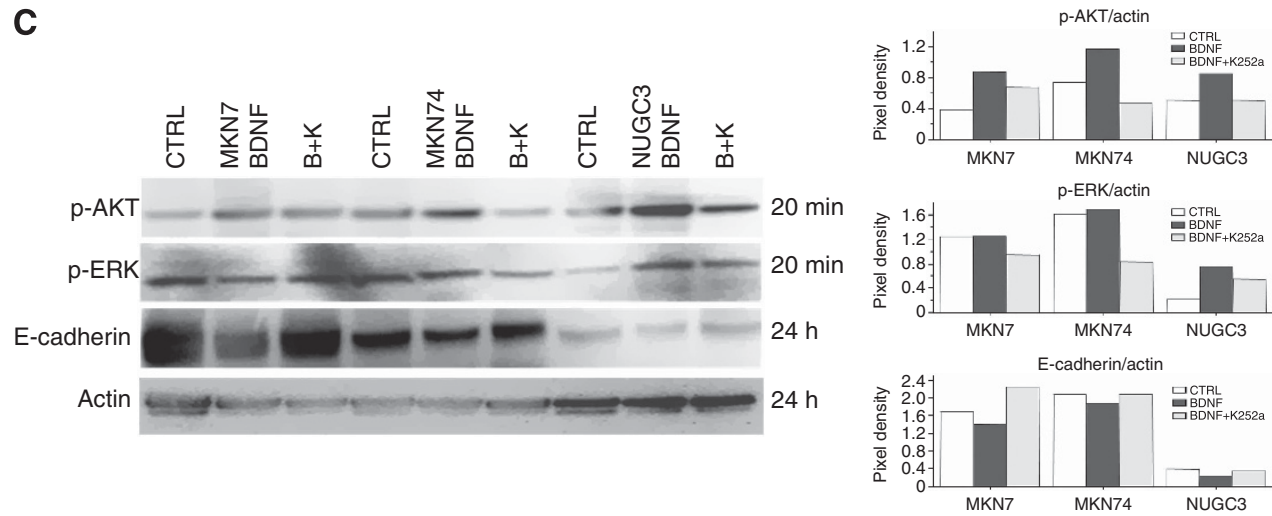

Figure 2. (A) Semi-quantitative RT-PCR analysis to detect BDNF and TrkB transcript expression in gastric cancer cell lines. The panel on the right shows densitometry analysis results. (B) Western blotting analysis to detect BDNF and TrkB protein expression in gastric cancer cell lines.

(C) Treatment with BDNF $\left(100 \mathrm{ng} \mathrm{ml}^{-1}\right)$ or $\mathrm{K} 252 \mathrm{a}(50 \mathrm{nM})$ followed by BDNF(100 $\left.\mathrm{ng} \mathrm{ml}^{-1}\right)$ stimulated p-AKT, p-ERK, and E-cadherin expression in MKN7, MKN74, and NUGC3 cells. The panel on the right shows densitometry analyses of expression levels normalised to actin.

Brain-derived neutrophic factor promotes migration and invasion in gastric cancer cells expressing TrkB in vitro. In wound-healing assays, an increased migratory effect was observed in rhBDNF-treated cells compared with untreated cells, and those treated with K252a followed by rhBDNF inhibited the migratory effect in all three cell lines tested (Figure 3B).

In invasion assays, the capacity of rhBDNF-treated MKN7 and NUGC3 cells to invade through a Matrigel-coated membrane was significantly greater than that of untreated cells (Figure 3C). K252a treatment followed by rhBDNF significantly reduced the number of invading cells in these cell lines. Treatment with K252a without rhBDNF induced a significant reduction in invasiveness compared with that of untreated cells in a part of gastric cancer cell lines. MKN74 cells did not exhibit invasion following rhBDNF treatment (data not shown).

Brain-derived neutrophic factor induced anoikis resistance in gastric cancer cells expressing TrkB in vitro. Because anoikis is known to induce apoptosis by loss of cell adhesion, we evaluated by MTT assay the number of viable MKN7, MKN74, and NUGC3 cells that were floating in low-attachment plates. The BDNF treatment caused an increase in the number of floating-viable gastric cancer cells, which was significantly higher than that of the control cells in all three gastric cancer cell lines tested. In gastric cancer cells treated with K252a followed by rhBDNF, the effect of rhBDNF was inhibited (Figure 3D).

In vivo assay. To assess whether $\mathrm{K} 252 \mathrm{a}$ inhibited tumour growth or peritoneal dissemination, we administered NUGC3 cells, a diffuse-type cell line that produces BDNF, intraperitoneally $\left(2 \times 10^{6}\right.$ cells per $\left.1 \mathrm{ml}\right)$ into nude mice. Peritoneal dissemination of NUGC3 cells was confirmed by laparotomy 14 days after intraperitoneal administration. Mice with peritoneal dissemination were randomised into two groups: intraperitoneal administration of $1 \mathrm{ml}$ dissolved $\mathrm{K} 252 \mathrm{a}\left(500 \mu \mathrm{g} \mathrm{kg}^{-1}\right)(n=5)$ or intraperitoneal administration of $1 \mathrm{ml}$ PBS $(n=5)$ every 3 days. The abdominal wall was closed after administration of K252a or PBS. Finally, we evaluated the tumour size and number of peritoneal dissemination sites, and the mice were killed after 35 days (Figure 4A). The tumour number and size in the K252a-treatment group were significantly lower than that of the control group (Figure 4B-E).

\section{DISCUSSION}

The major finding of the present study is that immnohistochemical analysis showed BDNF expression to be significantly increased in gastric cancer tissue compared with adjacent normal mucosa. In cancerous gastric tissue, BDNF was overexpressed at the invasive front of primary gastric cancer compared with the corresponding tumour core. In vitro experiments revealed that gastric cancer cell lines expressed BDNF. Although BDNF was initially identified as a protein secreted by neurons that affects nervous system development, recent studies suggest that BDNF is also produced in several types of cancer, including tumours arising from non-neural tissues(Yang et al, 2005; Brunetto de Farias et al, 2010). The present study is the first to demonstrate BDNF expression in gastric cancer samples and cell lines.

Another major finding of this study is that overexpression of BDNF at the invasive front has significant correlation with vessel 
A
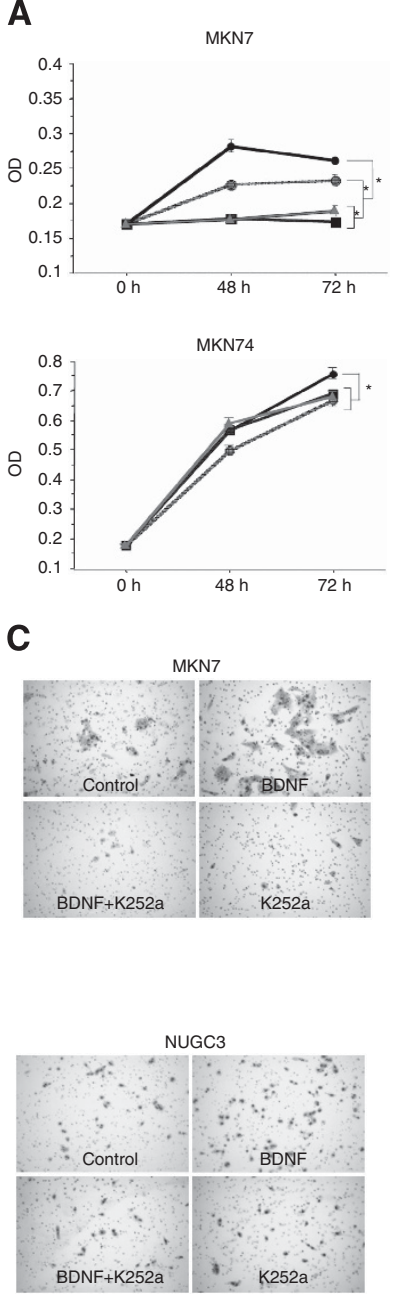

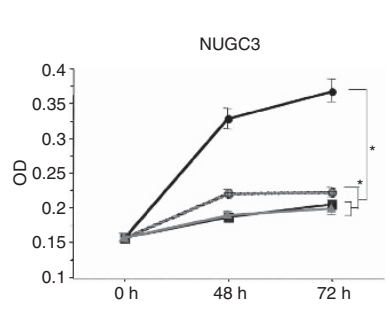

- Control

- BDNF $100 \mathrm{ng} / \mathrm{ml}$

- $\operatorname{BDNF}(100 \mathrm{nh} / \mathrm{ml})+\mathrm{K} 252 \mathrm{a}(50 \mathrm{nM})$

A- K252a(50nm)
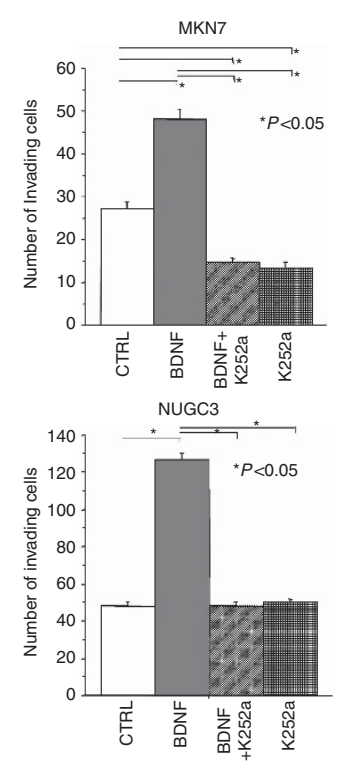

B
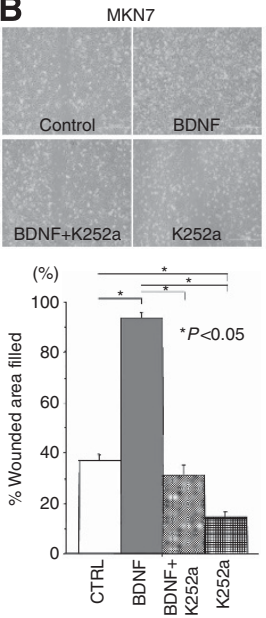
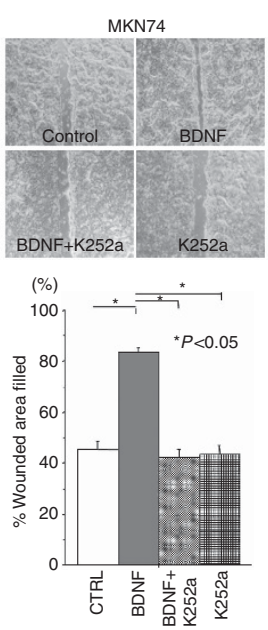
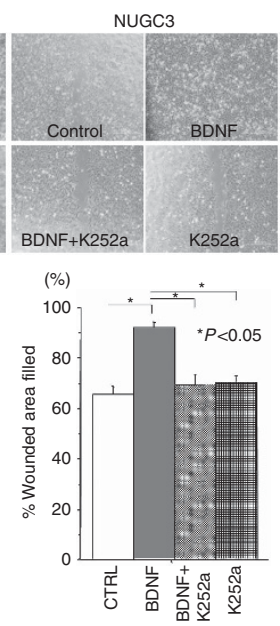
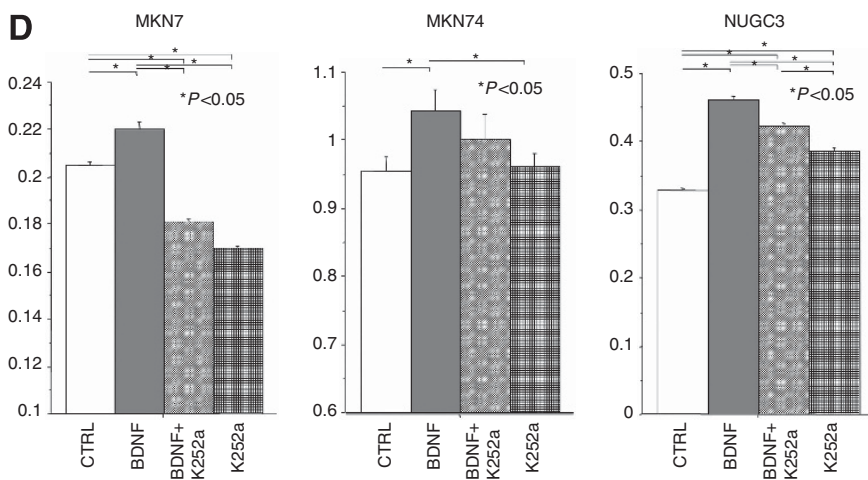

Figure 3. (A) A proliferation assay after 48 and $72 \mathrm{~h}$ to investigate the proliferative effects of BDNF (100 ng ml $\left.{ }^{-1}\right), \mathrm{K} 252 \mathrm{a}(50 \mathrm{nM})$, or $\mathrm{K} 252 \mathrm{a}(50 \mathrm{nM})$ followed by BDNF treatment (100 $\mathrm{ng} \mathrm{ml}^{-1}$ ) in MKN7, MKN74, and NUGC3 cells. (B) Migration scratch assay to investigate the migratory potential of MKN7, MKN74, and NUGC3 cells after treatment with BDNF (100 ng ml ${ }^{-1}$ ), K252a (50 nM), or K252a (50 nM) followed by BDNF treatment $\left(100 \mathrm{ng} \mathrm{ml}^{-1}\right)$. (C) Invasion assays demonstrated that the invasive capability of MKN7 and NUGC3 cells was significantly increased by BDNF treatment $\left(100 \mathrm{ng} \mathrm{ml}^{-1}\right)$ compared with untreated cells, cells treated with K252a ( $\left.50 \mathrm{nM}\right)$, or K252a (50 nM) followed by BDNF (100 ng ml ${ }^{-1}$ ) (D) Anoikis assay to investigate the anoikis resistance of MKN7, MKN74, and NUGC3 cells after treatment with BDNF (100 ng ml $\left.{ }^{-1}\right), \mathrm{K}^{252 a}$ $(50 \mathrm{nM})$, or $\mathrm{K} 252 \mathrm{a}(50 \mathrm{nM})$ followed by BDNF treatment $\left(100 \mathrm{ng} \mathrm{ml}^{-1}\right)$. After anoikis induction for $18 \mathrm{~h}$, an anoikis assay was performed and the number of viable floating cancer cells in low-attachment plates was calculated by MTT assay.

involvement, lymph node metastasis, peritoneal dissemination, and poor prognosis in gastric cancer patients. Interestingly, BDNF upregulation at the invasive front compared with the core is similarly significantly associated with poor prognosis. In addition, our study demonstrated that elevated co-expression of BDNF and TrkB at the tumour-invasive front was significantly correlated with lymph node metastasis and poor prognosis in these patients. Several reports described the correlation between the BDNF/TrkB pathway and poor prognosis in other types of cancer (Nakagawara et al, 1994; Asgharzadeh et al, 2006; Patani et al, 2011). Recently, Patani et al (2011) demonstrated that higher levels of BDNF transcripts were associated with unfavourable pathological parameters and poor prognosis in breast cancer patients. Our results suggested that $\mathrm{BDNF} / \mathrm{TrkB}$ expression at the invasive front of primary tumours could be useful as a potential prognostic biomarker for gastric cancer patients and that the BDNF/TrkB pathway might be strongly involved in gastric cancer disease progression.
For several types of cancer, tumour cells at the invasive front are considered to have a more aggressive behaviour compared with those in the more central region (Cianchi et al, 2010; AlpizarAlpizar et al, 2011; Tsutsumi et al, 2011) and are characterised by a dynamic process referred to as epithelial mesenchymal transition (EMT) (Brabletz et al, 2001; Spaderna et al, 2006). Epithelial mesenchymal transition is considered to be a transient and reversible process, and represents only one of the several steps required for tumour progression via invasion and metastatic spread (Sleeman, 2000), because it has also been implicated in the fundamental steps of tumorigenesis, such as invasion and metastasis (Allan et al, 2008). In particular, several studies indicated that $\operatorname{TrkB}$ signalling enhanced cancer cell migration and invasiveness via EMT-like changes, such as E-cadherin downregulation and vimentin upregulation (Smit et al, 2009; Kupferman et al, 2010; Dudas et al, 2011; Smit and Peeper, 2011; Fujikawa et al, 2012). Fujikawa et al (2012) demonstrated that E-cadherin expression in TrkB siRNA-transfected cells was higher 


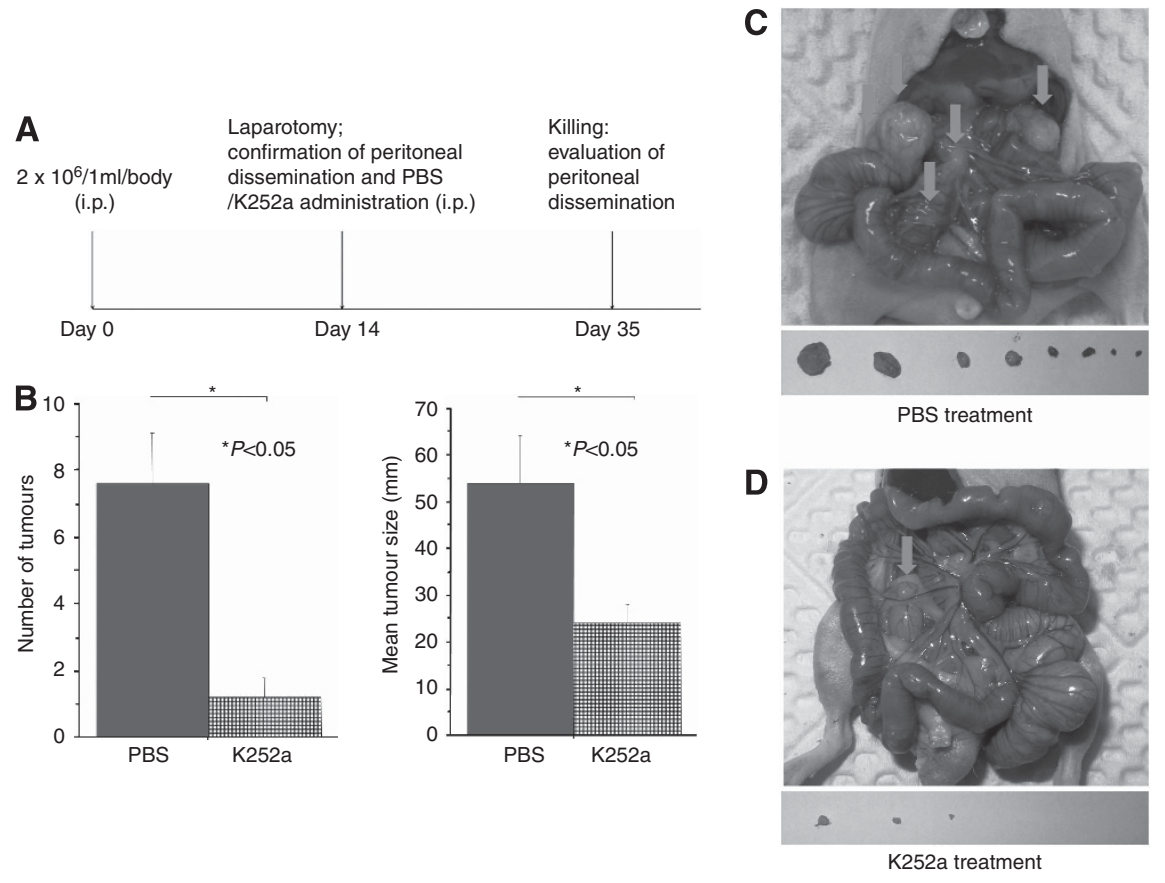

Figure 4. Suppression of peritoneal dissemination in mice by intraperitoneal administration of K252a. (A) Time schedule for establishing peritoneal dissemination, treatment, and evaluation. (B, C) Effect of K252a on peritoneal dissemination was assessed by counting the number of nodules and evaluating tumour size in the mesentery and peritoneal wall compared with controls. Five mice were used in each group. Each value represents mean \pm s.e. (D, E) K252a (5 $\mu \mathrm{m}$ per $1 \mathrm{ml}$ ) suppressed growth of NUGC3-induced nodules in the peritoneum compared with PBS (1 ml) on day 21 after treatment.

than that in control cells and promoted migration and invasiveness, suggesting that TrkB could induce EMT and have an important role in CRC progression. Kupferman et al (2010) also demonstrated that enforced TrkB overexpression results in altered expression of molecular mediators of EMT, including E-cadherin downregulation and upregulation of Twist, and was associated with invasiveness in head and neck squamous cell carcinoma. Our study also demonstrated that BDNF treatment downregulated E-cadherin expression in gastric cancer cells. In addition, the BDNF/ $\operatorname{TrkB}$ axis promoted cell migration and invasiveness in in vitro experiments. These results suggest that the BDNF/TrkB pathway might have a pivotal role in the migration and invasiveness of gastric cancer via EMT.

In cancer biology, metastasis is a pivotal event that determines the prognosis of patients with malignant disease. Metastasis from the primary site is established through multiple steps, with the first step being detachment of cancer cells from the primary tumour site (Engers and Gabbert, 2000; Fidler, 2002).

Anoikis is an apoptotic cell death that results from loss of or inappropriate cell-matrix interactions (Frisch and Francis, 1994). Dysregulation of anoikis, such as anoikis resistance, is a critical mechanism in tumour metastasis (Eccles and Welch, 2007). During metastasis, epithelial cancers spread to distinct organs through the blood stream. Tumour cells that acquire anoikis resistance can survive after detachment from their primary site and while travelling through the vascular system until they colonise distal organs (Simpson et al, 2008; Uekita et al, 2008; Kim et al, 2012; Taddei et al, 2012). In addition, anoikis resistance is important for peritoneal dissemination of gastric cancer and ovarian cancer cells (Uekita et al, 2008; Yokoe et al, 2010; Masoumi Moghaddam et al, 2012). Acquisition of resistance to anoikis is therefore a prerequisite for gastric cancer cells to survive in a detached state before they form metastatic foci and have a critical role in the progression of distant metastasis.
When gastric cancer cells were activated by BDNF in our study, TrkB in turn activated downstream signalling molecules, such as protein kinase B (Akt) and ERK, which are reported to promote cell proliferation and inhibit apoptosis through a number of downstream targets (Li et al, 2004; Simpson et al, 2007; Kawamura et al, 2010). Indeed, our present study revealed that BDNF treatment increased the proliferative activity and conferred anoikis resistance to all three TrkB-expressing gastric cancer cell lines tested. In addition, immnuhistochemical analysis demonstrated that disseminated gastric cancer cells of the lymph node and peritoneum expressed both BDNF and TrkB protein in the same pattern as that observed at the primary lesion in the same patient. Interestingly, our in vivo study demonstrated that the Trk antagonist K252a suppressed the peritoneal dissemination of BDNF autocrine gastric cancer cells, although limited by the factor that pan-Trk antagonist K252a, which also blocks other Trk (TrkA and TrkC) signalling, might be involved in the in vivo effect of K252a. Recently, activation of the BDNF/TrkB pathway was demonstrated to participate in the cellular mechanism for anoikis resistance in several cancer models, such as liver (Zhang et al, 2008, 2009), pancreatic (Sclabas et al, 2005), and ovarian cancers (Yu et al, 2008). Ng et al (2012) demonstrated that BDNF/TrkB signalling was deeply involved in anoikis resistance and that K252a harboured potent anoikis-sensitisation activity against nasopharyngeal cancer cells. Our findings here suggest that cancer cells at the invasive front of primary tumours acquired proliferation ability and anoikis resistance via the BDNF/TrkB pathway. This mechanism might sustain the anti-apoptotic state of detached cells as they disseminate from the primary tumour to metastatic sites and promote viable lymph node or peritoneal metastasis.

One of the possible roles of BDNF/TrkB in cancer is protecting tumour cells from anticancer therapy. For example, BDNF has been shown to protect neuroblastoma cells against etoposide (Li et al, 2011). In CRC, BDNF/TrkB signalling may offer 
protection from the antitumour effects of agents targeted to specific growth factor receptors, including anti-EGFR antibodies (Brunetto de Farias et al, 2010; de Farias et al, 2012). Although our study also evaluated whether K252a treatment induced 5fluorouracil sensitivity in vitro, K252a treatment did not affect the anti-tumour activity of 5-fluorouracil (data not shown). However, because the effects of other anticancer or molecularly targeted drugs on K252a treatment could not be evaluated, there remains the possibility that $\mathrm{BDNF} / \mathrm{TrkB}$ signalling may have a protective effect against anti-tumoural drugs and have a stimulatory role in cancer cell survival and cancer progression in gastric cancer.

In conclusion, we demonstrate the clinical and biological function of the BDNF/TrkB pathway in gastric cancer and provide the first evidence that the BDNF/TrkB pathway has an important role in invasion and metastasis of gastric cancer. Assessment of the BDNF and TrkB expression status in primary tumours provides clinically useful prognostic information for gastric cancer patients and indicates that the BDNF/TrkB pathway might be a novel therapeutic target for developing gastric cancer treatments.

\section{ACKNOWLEDGEMENTS}

We thank Motoko Ueeda and Chihiro Hibi for providing excellent technical assistance. This work was supported in part by a Grant in Aid for Scientific Research (B: 23791525) from the Ministry of Education, Culture, Sports, Science, and Technology, Japan.

\section{REFERENCES}

Allan GJ, Beattie J, Flint DJ (2008) Epithelial injury induces an innate repair mechanism linked to cellular senescence and fibrosis involving IGFbinding protein-5. J Endocrinol 199: 155-164.

Alpizar-Alpizar W, Christensen IJ, Santoni-Rugiu E, Skarstein A, Ovrebo K, Illemann M, Laerum OD (2011) Urokinase plasminogen activator receptor on invasive cancer cells: A prognostic factor in distal gastric adenocarcinoma. Int J Cancer 131(4): E329-E336.

Aoyama M, Asai K, Shishikura T, Kawamoto T, Miyachi T, Yokoi T, Togari H, Wada Y, Kato T, Nakagawara A (2001) Human neuroblastomas with unfavorable biologies express high levels of brain-derived neurotrophic factor mRNA and a variety of its variants. Cancer Lett 164: 51-60.

Asgharzadeh S, Pique-Regi R, Sposto R, Wang H, Yang Y, Shimada H, Matthay K, Buckley J, Ortega A, Seeger RC (2006) Prognostic significance of gene expression profiles of metastatic neuroblastomas lacking MYCN gene amplification. J Natl Cancer Inst 98: 1193-1203.

Brabletz T, Jung A, Reu S, Porzner M, Hlubek F, Kunz-Schughart LA, Knuechel R, Kirchner T (2001) Variable beta-catenin expression in colorectal cancers indicates tumor progression driven by the tumor environment. Proc Natl Acad Sci USA 98: 10356-10361.

Brunetto de Farias C, Rosemberg DB, Heinen TE, Koehler-Santos P, Abujamra AL, Kapczinski F, Brunetto AL, Ashton-Prolla P, Meurer L, Reis Bogo M, Damin DC, Schwartsmann G, Roesler R (2010) BDNF/TrkB content and interaction with gastrin-releasing peptide receptor blockade in colorectal cancer. Oncology 79: 430-439.

Cianchi F, Cuzzocrea S, Vinci MC, Messerini L, Comin CE, Navarra G, Perigli G, Centorrino T, Marzocco S, Lenzi E, Battisti N, Trallori G, Masini E (2010) Heterogeneous expression of cyclooxygenase-2 and inducible nitric oxide synthase within colorectal tumors: correlation with tumor angiogenesis. Dig Liver Dis 42: 20-27.

de Farias CB, Heinen TE, Dos Santos RP, Abujamra AL, Schwartsmann G, Roesler R (2012) BDNF/TrkB signaling protects HT-29 human colon cancer cells from EGFR inhibition. Biochem Biophys Res Commun 425: 328-332.

Douma S, Van Laar T, Zevenhoven J, Meuwissen R, Van Garderen E, Peeper DS (2004) Suppression of anoikis and induction of metastasis by the neurotrophic receptor TrkB. Nature 430: 1034-1039.
Dudas J, Bitsche M, Schartinger V, Falkeis C, Sprinzl GM, Riechelmann H (2011) Fibroblasts produce brain-derived neurotrophic factor and induce mesenchymal transition of oral tumor cells. Oral Oncol 47: 98-103.

Eccles SA, Welch DR (2007) Metastasis: recent discoveries and novel treatment strategies. Lancet 369: 1742-1757.

Engers R, Gabbert HE (2000) Mechanisms of tumor metastasis: cell biological aspects and clinical implications. J Cancer Res Clin Oncol 126: 682-692.

Ferlay J, Shin HR, Bray F, Forman D, Mathers C, Parkin DM (2010) Estimates of worldwide burden of cancer in 2008: GLOBOCAN 2008. Int J Cancer 127: 2893-2917.

Fidler IJ (2002) Critical determinants of metastasis. Semin Cancer Biol 12: 89-96.

Frisch SM, Francis H (1994) Disruption of epithelial cell-matrix interactions induces apoptosis. J Cell Biol 124: 619-626.

Fujikawa H, Tanaka K, Toiyama Y, Saigusa S, Inoue Y, Uchida K, Kusunoki M (2012) High TrkB expression levels are associated with poor prognosis and EMT induction in colorectal cancer cells. J Gastroenterol 47: 775-784.

Huang YT, Lai PC, Wu CC, Cheng CC, Chiu TH (2010a) TrkB antibody elicits cytotoxicity and suppresses migration/invasion of transitional cell carcinoma cells. Int J Oncol 37: 943-949.

Huang YT, Lai PC, Wu CC, Hsu SH, Cheng CC, Lan YF, Chiu TH (2010b) BDNF mediated TrkB activation is a survival signal for transitional cell carcinoma cells. Int J Oncol 36: 1469-1476.

Kahlert C, Lahes S, Radhakrishnan P, Dutta S, Mogler C, Herpel E, Brand K, Steinert G, Schneider M, Mollenhauer M, Reissfelder C, Klupp F, Fritzmann J, Wunder C, Benner A, Kloor M, Huth C, Contin P, Ulrich A, Koch M, Weitz J (2011) Overexpression of ZEB2 at the invasion front of colorectal cancer is an independent prognostic marker and regulates tumor invasion in vitro. Clin Cancer Res 17: 7654-7663.

Kawamura N, Kawamura K, Manabe M, Tanaka T (2010) Inhibition of brainderived neurotrophic factor/tyrosine kinase B signaling suppresses choriocarcinoma cell growth. Endocrinology 151: 3006-3014.

Kim YN, Koo KH, Sung JY, Yun UJ, Kim H (2012) Anoikis resistance: an essential prerequisite for tumor metastasis. Int J Cell Biol 2012: 306879.

Kupferman ME, Jiffar T, El-Naggar A, Yilmaz T, Zhou G, Xie T, Feng L, Wang J, Holsinger FC, Yu D, Myers JN (2010) TrkB induces EMT and has a key role in invasion of head and neck squamous cell carcinoma. Oncogene 29: 2047-2059.

Lewin GR, Barde YA (1996) Physiology of the neurotrophins. Annu Rev Neurosci 19: 289-317.

Li J, Melvin WS, Tsai MD, Muscarella P (2004) The nuclear protein p34SEI-1 regulates the kinase activity of cyclin-dependent kinase 4 in a concentration-dependent manner. Biochemistry 43: 4394-4399.

Li Z, Oh DY, Nakamura K, Thiele CJ (2011) Perifosine-induced inhibition of Akt attenuates brain-derived neurotrophic factor/TrkB-induced chemoresistance in neuroblastoma in vivo. Cancer 117: 5412-5422.

Masoumi Moghaddam S, Amini A, Morris DL, Pourgholami MH (2012) Significance of vascular endothelial growth factor in growth and peritoneal dissemination of ovarian cancer. Cancer Metastasis Rev 31: 143-162.

Miknyoczki SJ, Lang D, Huang L, Klein-Szanto AJ, Dionne CA, Ruggeri BA (1999) Neurotrophins and Trk receptors in human pancreatic ductal adenocarcinoma: expression patterns and effects on in vitro invasive behavior. Int J Cancer 81: 417-427.

Montano X, Djamgoz MB (2004) Epidermal growth factor, neurotrophins and the metastatic cascade in prostate cancer. FEBS Lett 571: 1-8.

Nakagawara A, Azar CG, Scavarda NJ, Brodeur GM (1994) Expression and function of TRK-B and BDNF in human neuroblastomas. Mol Cell Biol 14: 759-767.

Ng YK, Wong EY, Lau CP, Chan JP, Wong SC, Chan AS, Kwan MP, Tsao SW, Tsang CM, Lai PB, Chan AT, Lui VW (2012) K252a induces anoikissensitization with suppression of cellular migration in Epstein-Barr virus (EBV)-associated nasopharyngeal carcinoma cells. Invest New Drugs 30: $48-58$.

Patani N, Jiang WG, Mokbel K (2011) Brain-derived neurotrophic factor expression predicts adverse pathological \& clinical outcomes in human breast cancer. Cancer Cell Int 11: 23.

Ricci A, Greco S, Mariotta S, Felici L, Bronzetti E, Cavazzana A, Cardillo G, Amenta F, Bisetti A, Barbolini G (2001) Neurotrophins and neurotrophin receptors in human lung cancer. Am J Respir Cell Mol Biol 25: 439-446.

Sclabas GM, Fujioka S, Schmidt C, Li Z, Frederick WA, Yang W, Yokoi K, Evans DB, Abbruzzese JL, Hess KR, Zhang W, Fidler IJ, Chiao PJ (2005) Overexpression of tropomysin-related kinase B in metastatic human pancreatic cancer cells. Clin Cancer Res 11: 440-449. 
Segal RA, Greenberg ME (1996) Intracellular signaling pathways activated by neurotrophic factors. Annu Rev Neurosci 19: 463-489.

Simpson CD, Anyiwe K, Schimmer AD (2008) Anoikis resistance and tumor metastasis. Cancer Lett 272: 177-185.

Simpson PJ, Moon C, Kleman AM, Connolly E, Ronnett GV (2007) Progressive and inhibitory cell cycle proteins act simultaneously to regulate neurotrophin-mediated proliferation and maturation of neuronal precursors. Cell Cycle 6: 1077-1089.

Sleeman JP (2000) The lymph node as a bridgehead in the metastatic dissemination of tumors. Recent Results Cancer Res 157: 55-81.

Smit MA, Geiger TR, Song JY, Gitelman I, Peeper DS (2009) A twist-snail axis critical for TrkB-induced epithelial-mesenchymal transition-like transformation, anoikis resistance, and metastasis. Mol Cell Biol 29: 3722-3737.

Smit MA, Peeper DS (2011) Zeb1 is required for TrkB-induced epithelialmesenchymal transition, anoikis resistance and metastasis. Oncogene 30: 3735-3744.

Spaderna S, Schmalhofer O, Hlubek F, Berx G, Eger A, Merkel S, Jung A, Kirchner T, Brabletz T (2006) A transient, EMT-linked loss of basement membranes indicates metastasis and poor survival in colorectal cancer. Gastroenterology 131: 830-840.

Taddei ML, Giannoni E, Fiaschi T, Chiarugi P (2012) Anoikis: an emerging hallmark in health and diseases. J Pathol 226: 380-393.

Tanaka K, Mohri Y, Nishioka J, Kobayashi M, Ohi M, Miki C, Tonouchi H, Nobori T, Kusunoki M (2009) Neurotrophic receptor, tropomyosinrelated kinase B as an independent prognostic marker in gastric cancer patients. J Surg Oncol 99: 307-310.

Toiyama Y, Inoue Y, Yasuda H, Saigusa S, Yokoe T, Okugawa Y, Tanaka K, Miki C, Kusunoki M (2011) DPEP1, expressed in the early stages of colon carcinogenesis, affects cancer cell invasiveness. J Gastroenterol 46: 153-163.

Tsutsumi S, Morohashi S, Kudo Y, Akasaka H, Ogasawara H, Ono M, Takasugi K, Ishido K, Hakamada K, Kijima H (2011) L1 Cell adhesion molecule (L1CAM) expression at the cancer invasive front is a novel prognostic marker of pancreatic ductal adenocarcinoma. J Surg Oncol 103: 669-673.

Uekita T, Tanaka M, Takigahira M, Miyazawa Y, Nakanishi Y, Kanai Y, Yanagihara K, Sakai R (2008) CUB-domain-containing protein 1 regulates peritoneal dissemination of gastric scirrhous carcinoma. Am J Pathol 172: $1729-1739$.

Workman P, Aboagye EO, Balkwill F, Balmain A, Bruder G, Chaplin DJ, Double JA, Everitt J, Farningham DA, Glennie MJ, Kelland LR, Robinson V, Stratford IJ, Tozer GM, Watson S, Wedge SR, Eccles SA (2010) Guidelines for the welfare and use of animals in cancer research. Br J Cancer 102: 1555-1577.

Yang ZF, Ho DW, Lam CT, Luk JM, Lum CT, Yu WC, Poon RT, Fan ST (2005) Identification of brain-derived neurotrophic factor as a novel functional protein in hepatocellular carcinoma. Cancer Res 65: 219-225.

Yokoe T, Toiyama Y, Okugawa Y, Tanaka K, Ohi M, Inoue Y, Mohri Y, Miki C, Kusunoki M (2010) KAP1 is associated with peritoneal carcinomatosis in gastric cancer. Ann Surg Oncol 17: 821-828.

Yu X, Liu L, Cai B, He Y, Wan X (2008) Suppression of anoikis by the neurotrophic receptor TrkB in human ovarian cancer. Cancer Sci 99: 543-552.

Zhang Z, Cao L, Li J, Liang X, Liu Y, Liu H, Du J, Qu Z, Cui M, Liu S, Gao L, Ma C, Zhang L, Han L, Sun W (2008) Acquisition of anoikis resistance reveals a synoikis-like survival style in BEL7402 hepatoma cells. Cancer Lett 267: 106-115.

Zhang Z, Han L, Liu Y, Liang X, Sun W (2009) Up-regulation of Tropomyosin related kinase $\mathrm{B}$ contributes to resistance to detachment-induced apoptosis in hepatoma multicellular aggregations. Mol Biol Rep 36: 1211-1216.

This work is published under the standard license to publish agreement. After 12 months the work will become freely available and the license terms will switch to a Creative Commons AttributionNonCommercial-Share Alike 3.0 Unported License.

Supplementary Information accompanies this paper on British Journal of Cancer website (http://www.nature.com/bjc) 